\title{
Research Review on the Relationship between Corporate Governance and Accounting Information Disclosure
}

\author{
Leilei Zhang \\ School of accounting, Shandong Management University, Ji'nan 2503573, China
}

Keywords: Corporate governance, Accounting information disclosure, Control of earnings, Irregularities.

\begin{abstract}
Accounting information disclosure has been a hot issue in the field of accounting and corporate governance all the time. The author has consulted related literatures, and pays attention to the latest foreign literature particularly, so as to sort out the research status of corporate governance and accounting information disclosure, On this basis the author has put forward the theoretical basis that the future research should further enrich that field; for the internal, the research should deep dive into the board of directors, the manager level behaviors, study on how the governance structure will influence the information disclosure through the governance behavior ; for the external, the research should consider the effect on corporate governance and information disclosure from product market competition, so as to perfect the research framework in this field.
\end{abstract}

\section{Introduction}

With the continuous improvement of the world financial market, investors have a more and more high demand for the quality of accounting information disclosure. No matter it is voluntary information disclosure or mandatory information disclosure, they are all highly valued by the information demanders. However the financial fraud cases from listed corporations in China are emerging in an endless stream, the phenomenon of accounting information fraud has become an international problem. This article reviews the relevant literatures in this field, especially pay attention to the latest foreign literatures in recent years, puts forward the limitations of the present study on this basis, so as to provide ideas for future research.

\section{Theoretical basis- agency theory}

Agency theory is the theoretical basis of the study for traditional corporate governance. Agency theory takes enterprises as "an aggregation of a series of complex contracts (written and unwritten) among individuals" (Jensen 1983; Spence and Zeckhauser 1971; Ross 1973). The agency relationship is an agreement, one party (the principal) employs the other party (the agent) to conduct business activities on behalf of them, including grant the agent the decision-making authority.

In modern corporation which ownership separate from management right, the shareholder is a principal, and the manager is an agent. Agency theory believes that shareholders may face moral hazard and adverse selection of managers, which is the agency problem. In order to solve the agency problem, and keep the interests of manager level consistent with that of shareholders, the formal incentive and supervision mechanism of corporate governance is established. (Fama and Jensen, 1983).

Based on the principal of agent theory, the scholars and practitioners basically agree that the main function of corporate governance is control, Stockholders observe the behavior of the managers directly or indirectly through the supervision mechanism (Jensen and Meckling, 1976), and reduce information asymmetry in order to restrain the opportunism behavior of managers; Coordinate the interests of management level and shareholders through incentive mechanism, keep their goals and interests consistent. The various components of the corporate governance mechanism-- supervision of the board of directors and the controlling shareholders, supervision of the board of supervisors , 
motivation of manager level , external product market competition, takeover of market control right, debt and bankruptcy constraints, information disclosure and social media, etc., which are all regarded as the products of the joint-stock companies. Through the establishment of these corporate governance mechanisms, the behavior of the managers can be effectively controlled, shareholders' rights can be protected and company value can reach to maximization, also agency problem is solved. Obviously, accounting information disclosure,as an important corporate governance mechanism, plays an important role in solving the agency problem .

\section{Research on the influence on accounting information disclosure from corporate governance}

Domestic and foreign scholars have studied the relationship between corporate governance and accounting information disclosure for many years, most of them have focused on the impact of the quality for accounting information disclosure from all aspects of the internal corporate governance. It can be generally divided into the following several angles:

\section{Research on the influence of accounting information disclosure from stock ownership structure.}

Under the condition of the separation of ownership and management rights(Berleand Means,1932), the role of accounting information disclosure is to reduce the information asymmetry between shareholders and managers, which is conducive to the supervision of the shareholders to the manager, reduce the opportunism behavior of managers and reduce agency costs . However, different from two power highly dispersed background proposed by Berle and Means (1932) ,the studies from Demsetz (1983)、Shleifer, Vishny(1986)and Morck (1988) all shows that the ownership concentration is also common in the United States. The absolute controlling shareholders under the concentration ownership and the controlling shareholders in the relative concentration of equity, because they own large number of shares, they will have the power and the ability to implement the supervision and control behavior(Jensen and Meckling, 1976 ; Shleifer and Vishny, 1986).At the same time, the major shareholders will also use their own decision-making power to seize the company wealth,gain control right and private benefits at the price of sacrificing the interests of small shareholders. The main agency problem in the ownership concentration is the expropriation of minority shareholders from major shareholders, so major shareholders can obtain control power andprivate benefits. Which is called tunneling.( Johnson etc., 2000； LLSV，2002; Shleifer and Wolfenzon,2002)

Major shareholders conduct financial fraud or earnings management, reduce the quality of information disclosure, and increase the degree of information asymmetry, so as to conceal his occupation activity. At the same time, in the equity concentration company, controlling shareholders may put pressure to management level or even replace managers to control the company through nominating delegates or senior managers (Weian Li, etc. $2009^{4}$ ), which also offers the possibility of their earnings manipulation. This view is supported by many scholars. For example, Wang Yuetang (2008) proves that the lack of checks and balances of equity has negative impact on the quality of financial information ${ }^{6}$; Yang Xiangyang and Wang Wenping(2009)consider that the ownership concentration and financial reporting fraud has significant positive correlation relationship; Chen Xiaolin and Linxi (2010) discover from the empirical study that if there is major shareholders occupation phenomenon in the company, the information disclosure transparency is lower, the higher effect of the big shareholder balance, the higher transparency of the information disclosure. But there are a few scholars holding different views, Huang Zhiliang, Zhou Changxin(2006) finds that the shareholding ratio of the largest shareholder has significantly positively relation to information disclosure quality. However, Wang Bin, Liang Xinxin(2008) discovery from evidence that there is no obvious relations between the company controlling shareholders and the quality of information disclosure.

This article considers that the reasons that there are some inconsistent conclusions lie in: Firstly, there is no further consideration for the character of stock right. Secondly, ignore the external market 
competition factors. Thirdly, fails to fully consider the mutual influence from the board of directors and other corporate governance level.

\section{Research on impact for accounting information disclosure from the governance of board of directors and board of supervisors.}

The board of directors is in the core position of corporate governance. Currently many existing problems in listed companies in our country such as corporate property is occupied or emptied by a major shareholder, financial distress, credit crisis or even illegal fraud, which are rooted in the invalid board governance. At present, there are many research achievements for the relationship between the board characteristics and quality of information disclosure, mainly study the quality of accounting information disclosure from the board scale, independence, and efficiency of the subprime committee of the board. Larelle Chapple et a.l (2008 )、 Nadia Smaili etc. (2009) discover from empirical findings that if there are less independent directors in company and no audit committee, it will reduce the quality of information disclosure. Generally speaking, Réal Labelle(2008)thinks that the board independence efficiency of the audit committee has a positive relationship with accounting information quality, But if the two indexes of incidence of false financial information and earning quality were used respectively to express the accounting information quality, the different characteristics of the board of directors and audit committee efficiency and the correlation of the above two indicators are distinct ${ }^{8}$. Chen Gongmeng et a.l (2005),Larelle Chapple et a.l (2008),Yang Lianzhong and Yin Zi(2006),Ye Kangtao(2007) proves that outside directors which has no correlation with the company can more effectively exercise the supervisory functions because of its higher objectivity, so as to reduce the agency cost , the earnings manipulation and financial fraud in modern enterprises.In addition, hold a concurrent post of both chairman and general manager may damage the independence of the board of directors, and cause the power expansion of CEO, which will provide convenience for the opportunism behave of general manager and form" insider control" of manager level, and it will be easy to cause the company's financial fraud and earnings management.

Obviously, the research on governance of the board of directors and accounting information quality has accumulated a lot of achievement, but it is still in a state of mess in many issues, in addition to the differences of the research methods and the choice of sample, ignorance of the behavior research of the board of directors is also one of the important reasons. Future research will continue to explore the approach that characteristics of the board of directors which will impact financial fraud, embezzlement, corruption and false financial information ${ }^{9}$.

\section{Research on the effects of accounting information disclosure from managers.}

Managers' level as actuators of corporate decision has direct responsibility for the company's business. Agency theory thinks that because the interest inconsistency between principal and agent and the selfishness of managers, thus decisions of managers may damage the interests of the shareholders. From the theoretical analysis, opportunistic behavior of managers can be reduced by giving managers the right incentives and the interests coordination of managers and shareholders. But many studies have shown that equity incentive of manager level of doesn't reduce any agency costs, instead it provides a motive of income smoothing. For example Warren (2011) thinks that stock options will promote the financial fraud of CEO, and cash wages and bonuses will have indirect effects on financial fraud only through stock options ${ }^{10}$. For enterprises in China, due to the weakening of internal governance mechanism, operators use the equity incentive mechanism to rob the shareholders' interests for their own profits. Wang Kemin, Wang Zhichao(2007) and Li Yanxi(2008) find that executive compensation constitutes a basic cause of earnings management in China's listed companies

In recent years, foreign literatures tend to study the accounting information quality from the perspective of finance such as management behavior. Hribar and Yang(2007) proves that CEO of overconfidence is more likely to public earnings forecast that is too optimistic, and will pursuit earnings management in order to achieve earnings forecast ${ }^{11 .}$ Cohena(2009) discovers from the research that managers personal characteristics are important influence factors of financial fraud ${ }^{12}$. 
Schrand(2010) proves from evidences that managers' overconfidence will increase the likelihood of financial fraud ${ }^{13}$. There is little research on this aspect in China, our market economy is still in a perfecting stage, and manager market is far from mature, manager's irrational behavior is likely to be more prominent, so the study of accounting information disclosure from manager's personal characteristics should be strengthened. When establishing the model, the difficulty lies in that the explanation variables for the measurement of overconfidence need to be further discussed.

\section{Research on the impact on corporate governance from the quality of accounting information disclosure}

From above discussion we can see that high quality accounting information disclosure is conducive to enhance the efficiency of corporate governance, and then it can reach to a virtuous circle between the quality of information disclosure and the effects of corporate governance. Wang Kemin (2009) finds that information transparency of listed companies has significant correlation with the degree of capital takes up from big shareholders, the higher the earnings aggressiveness and the total earnings opacity, the more serious the big shareholder's behavior of capital take up is.

Aliza(2011) thinks that after the report repeats (including fraud) of the company, corporate governance structure including the board of directors, audit and management level will change, so as to improve related issue that cause the report restatement ${ }^{14}$. Hermalin (2011) discovers from the empirical study that too much disclosure of accounting information is a two-edged sword: on one hand, the sufficient information disclosure can help consignors make better decisions; on the other hand, too much disclosure of accounting information will produce more pressure to managers, they are more likely to provide false accounting information by fraud.

\section{Research summary}

a). From the previous literature review we can see that in the empirical studies, the measurement of the quality of accounting information disclosure is different. In current literatures, there are several major ways to measure the quality of information disclosure: Gao Qiang, Wu Lina(2008) adopt the evaluation results of the listing corporate information disclosure from Shenzhen Stock Exchange as a measure index of the quality of accounting information disclosure 16. Wang Yuetang(2008) uses the market reaction coefficient which is generally used in western academic circle to determine the relevance of financial information value and evaluate the quality of financial information 17; Jones(2000)、McDaniel(2002)、Cohen(2004)、Lan Wenyong and Wei Mingsheng(2009) use the reverse of earnings management to measure the quality of accounting information18; In the research and design of Luo Xinhua(2007),he take the listing corporation as a representative that will be punished by the SFC because the low quality of accounting information disclosure. On this issue, it is necessary to make some further exploration and extract scientific and reasonable measure index for the quality of information disclosure.

b). At present, most of the literatures only consider the level of governance structure and establish the direct logic relation between the governance structure and information disclosure. However, the impact on the disclosure of information from corporate governance may not be straightforward and simple. Many countries have corporate governance guidelines, If every company establishes a standard structure which in accordance with the requirements of laws and regulations, then the most basic resource differences will disappear. Under the standardization of corporate governance structure, there are still a big differences in the disclosures of information, this makes us have to go deep into the internal governance of the company and explore "black box" of the corporate governance operation.

c).Further consider the relationship between external market competition and corporate governance, accounting information disclosure. At present, some scholars have studied the relationship between the external market competition and the disclosure of accounting information, but there is still no consistent conclusion. Market competition as an external governance 
mechanism,interacts with internal governance. And, in the process of the corporate governance impacts on the performance, external market competition will have a certain impact on the effectiveness of corporate governance, which is interaction. Therefore the study related to major policies such as the choice of corporate governance mechanism, formulation of competition policy and reform of market economy has a very practical significance. At present, there are a very few scholars studying on this, this is the direction that should be further explored in the future.

d).Further enrich the theoretical basis of research in this field. Most of the current researches are confined to the framework of agency theory, the theory can not break through the organizational boundaries, and systematically review the overall impact on the effectiveness of corporate governance mechanisms from the organization's internal and external environment 。 As mentioned before, if study the information disclosure from the perspective of corporate governance behavior, researchers need to make a comprehensive definition and interpretation of governance behavior combined with resource dependence theory, stewardship theory and strategy theory, etc.

\section{References}

[1] Jensen MC, MecklingW. Theory of the firm: managerial behavior, agency costs and ownership structure. Journal of Financial Economics, 1976;3:305-60.

[2] Fama, E. F. and Jensen, M. C. Separation of ownership and control, Journal of Law and Economics, 1983, 26: 301-25.

[3] Shleifer,A. and Vishn y,R. W. Large shareholders and corporate control, Journal of Political Economy, 1986,94, 461-488.

[4] Wang Yuetang, Zhu Lin, Chen Shimin, Board independence, equity ratio restriction and financial information quality. Accounting Research, 2008 (1).

[5] Nadia Smaili , Réal Labelle.2009.Preventing and Detecting Accounting Irregularities: The Role of Corporate Governance. Working paper. papers.ssrn.com.

[6] Luo He , Réal Labelle, Charles Piot , Daniel B. Thornton . Board Monitoring, Audit Committee Effectiveness, and Financial Reporting Quality: Review and Synthesis of Empirical Evidence.Journal of Forensic \& Investigative Accounting, 1(2).

[7] Xie Yongzhen, Xu Yekun, Research review on corporate governance risk. Journal of Shandong University (Philosophy and Social Science Edition), 2009 (3).

[8] Warren Don, Zey Mary, Granston Tanya, Roy Joseph.2011. Earnings fraud: board control vs CEO control and corporate performance. Managerial \& Decision Economics, 32(1):17-34.

[9] Hribar P. and H. Yang. 2007. CEO Overconfidence, Management Earnings Forecasts, and Earnings Management.Working Paper, available online at http://papers. ssrn. com

[10]Luo He, Réal Labelle, Charles Piot, Daniel B. Thornton.2010. Corporate Fraud and Managers' Behavior: Evidence from the Press. http://papers.ssrn.com.

[11]Catherine M. Schrand, Sarah L. C. Zechman.2010. Executive Overconfidence and the Slippery Slope to Fraud. http://papers.ssrn.com.

[12]Rotenstein Aliza.2011. Corporate Governance Changes Following Earnings Restatements: A Research Tool. Journal of Applied Business Research, 27(1):123-140.

[13]Benjamin E. Hermalin, Michael S. Weisbach .2011. Information Disclosure and Corporate Governance. Working Paper. http://papers.ssrn.com.

[14]Gao Qiang, Wu Lina, Can holding the post of secretary of the board improve information disclosure quality? Accounting Research, 2008 (1) 
[15]Wang Yuetang, Zhu Lin, Chen Shimin, Board independence, equity ratio restriction and financial information quality. Accounting Research, 2008 (1).

[16]Lan Wenyong, Wei Mingsheng, Empirical study on influence of corporate governance structure on accounting information quality. Technoeconomics \& Management Research. 2009 (6). 